\title{
International Criminal Law and Legal Memories of Abolition: Intervention, Mixed Commission Courts and "Emancipation"1
}

\section{Abstract}

This article provides a critical reading of four cases that took place before nineteenth century Mixed Commissions on the Slave Trade at Sierra Leone, namely the Sinceridade, Activo, Perpetuo Defensor and Maria da Gloria cases. Mixed Commissions were early institutional sites where international law was confronted with victims on a multiple scale. Although they had the power to emancipate slaves, Mixed Commissions did not do so as a result of rights attributed to slaves as human beings. Rather this article shows that the capacity of Mixed Commissions to emancipate slaves was dependent upon the legality of the search, seizure and detention of the slave ship on which slaves were found. This legal link between emancipation and lawful intervention left slaves in a potentially precarious legal position even at the point of "rescue". However, in two of the cases examined here the worst effects of this precariousness were avoided through slave resistance. This article aims to contribute to ongoing scholarly critiques of international criminal legal histories by interrogating how abolition has been remembered in international law.

\footnotetext{
${ }^{1}$ The research for this article was made possible by an award from the Research Activities Fund of the Society of Legal Scholars, for which the author is extremely grateful. Earlier versions of this paper were given to the Centre on Human Rights in Conflict, University of East London, to the Lauterpacht Centre, University of Cambridge, and to Kent Law School. My thanks go to participants at these seminars for their helpful comments. My thanks also go to Rod Edmunds, Nick Piska and Bryan Scattergood for their insightful comments on previous drafts of this article and to Luis Eslava and Sara Kendall for many helpful discussions. I am also grateful for the many helpful and extensive comments of the anonymous reviewer.
} 


\section{Key words}

International Legal History; International Criminal Law; Mixed Commission Courts; Slavery and Abolition; the Sinceridade, Activo, Perpetuo Defensor and Maria da Gloria Cases.

\section{Introduction}

At a time when the legitimacy of international criminal law, more specifically the International Criminal Court's (ICC) focus on African situations, is profoundly affected by international law's historic implication in slavery and colonialism, ${ }^{2}$ the question of how international law's role in abolition can and should be narrated is of critical importance. This article considers this question through a critical reading of four slave trading cases before the British-Portuguese Mixed Commission at Sierra Leone, namely the Sinceridade, ${ }^{3}$ the Activo, ${ }^{4}$

\footnotetext{
${ }^{2}$ The colonial heritage of international law is well established: see, for example, Anthony Anghie, Imperialism, Sovereignty and the Making of International Law (Cambridge: Cambridge University Press 2005); Matthew Craven, 'Colonialism and Domination', in Bardo Fassbender/Anne Peters (eds), The Oxford Handbook of The History of International Law (Oxford: Oxford University Press 2014), 862-889. More specifically in international criminal law see the discussion in Frédéric Mégret, 'International criminal justice: A critical research agenda', in Christine Schwöbel (ed), Critical Approaches to International Criminal Law: An Introduction (Abingdon: Routledge 2014), 17-53 and Christopher Gevers, 'International criminal law and individualism: An African perspective', in Schwöbel (ed), Critical Approaches to International Criminal Law: An Introduction (Abingdon: Routledge 2014), 221-245.

${ }^{3}$ British-Portuguese Mixed Commission, The Sinceridade, Gregory and Fitzgerald to Canning, 22 April 1823, with enclosures, The National Archives (hereafter "TNA"): FO 84/22, 89.

${ }^{4}$ British-Portuguese Mixed Commission, The Activo, HM Commissioners to Canning, 10 June 1826, TNA: FO 84/49, 84 and accompanying Report of the Case, TNA: FO 84/49, 88.
} 
the Perpetuo Defensor, ${ }^{5}$ and the Maria da Gloria $^{6}$ with a view to contributing to the ongoing scholarly development of more multifaceted histories of international criminal law. ${ }^{7}$

Typically histories of international criminal law trace their origins to the Nuremberg and Tokyo Tribunals. However, the origins of international criminal law, or indeed any law, cannot be traced to a single source. Admittedly, Mixed Commissions were not criminal institutions as such. However, there are good reasons for incorporating them, and histories of abolition more generally, more firmly into histories of international criminal law. ${ }^{8}$ The significance of international abolition in international criminal legal histories is in no small

\footnotetext{
${ }^{5}$ British-Portuguese Mixed Commission, The Perpetuo Defensor, Hamilton to Canning, 12 October 1826, TNA:
} FO 84/49, 160 and accompanying Report of the Case, TNA: FO 84/49, 167.

${ }^{6}$ British-Portuguese Mixed Commission, The Maria da Gloria, HM Commissioners to Palmerston, 22 March 1834, TNA: FO 84/149, 22 and Report of the Case, TNA: FO 84/149, 39.

${ }^{7}$ See further, in the context of international criminal law for example, Kevin Jon Heller / Gerry Simpson (eds), The Hidden Histories of War Crimes Trials (New York, OUP 2013); Immi Tallgren, 'Searching for Historical Origins of International Criminal Law' in Morten Bergsmo/Cheah Wui Ling/Yi Ping (eds), Historical Origins of International Criminal Law: Volume I (Brussels: Torkel Opshal EPublisher 2014), xi-xxx.

${ }^{8}$ Despite numerous attempts on the part of the British Government, slave trading, which is now an international crime, was not recognised as a crime under the law of nations during this period. However, what is not included as a crime, and more specifically the reasons for its exclusion, form an important part of the discipline's history. There is not space to pursue this line of argument further here. Moreover, slave trading was also recognised as a crime in some national legislation see further Emily Haslam, 'Redemption, Colonialism and International Criminal Law: the nineteenth century slave trading trials of Samo and Peters', in Diane Kirkby (ed), Past Law, Present Histories: From Settler Colonies to International Justice. (Canberra: ANU e-press 2012), 7-22; Emily Haslam, 'Silences in International Criminal Legal Histories and the Construction of the Victim Subject of International Criminal Law: the Nineteenth-century Slave Trading Trial of Joseph Peters’ in Christine Schwöbel (ed), Critical Approaches to International Criminal Law: an introduction (London: Routledge 2014), 181-195. 
part contingent upon how international criminal law is understood. In so far as international criminal law can be understood as a historically contingent response to human rights violations, Mixed Commissions form part of the history of international institutional justice. They are also an early site where international law was confronted with mass victims. However, the significance of abolition in international criminal legal histories goes beyond attempts to trace a linear progression and causal link in legal principles and institutional design: abolition has particular resonance in the contemporary context in which it has been widely claimed that international criminal law has been marred by a north-south divide.

The British-Portuguese Mixed Commission was one of several bilateral tribunals established at Sierra Leone and elsewhere to adjudicate the legality of the detention of captured slave ships. ${ }^{9}$ These Mixed Commissions had the power to emancipate slaves or to restore them, with compensation, to those claiming ownership of them. In general abolition produced significant changes in international law. ${ }^{10}$ More specifically, Mixed Commissions were early institutional sites where international law was confronted with victims on a multiple scale. However, how Mixed Commissions and their work can and should be remembered is not

\footnotetext{
${ }^{9}$ For a recent account of Mixed Commissions in international law, see Jenny Martinez, The Slave Trade and the Origins of International Human Rights Law (Oxford: OUP 2012). See further Leslie Bethell, 'The Mixed Commissions for the Suppression of the Transatlantic Slave Trade in the Nineteenth Century', Journal of African History 7 (1966), 79-93; Farida Shaikh, 'Judicial Diplomacy British Officials and the Mixed Commission Courts' in Keith Hamilton / Patrick Salmon (eds), Slavery, Diplomacy and Empire Britain and the Suppression of the Slave Trade, 1807-1975 (Eastbourne: Sussex Academic Press 2012), 42-64.

${ }^{10}$ Seymour Drescher and Paul Finkelman, 'Slavery' in Bardo Fassbender/Anne Peters (eds), The Oxford Handbook of The History of International Law (Oxford: Oxford University Press 2014), 891-916, 904.
} 
simply a matter of archival retrieval. It involves weighty political and methodological choices.

Whereas historians have doubted the significance of Mixed Commissions to slave trade abolition as a whole, ${ }^{11}$ the lawyer, Jenny Martinez, has positioned them as 'the first international human rights courts'. ${ }^{12}$ Such a claim in part depends on how human rights themselves are seen. As Lauren Benton rightly observes, to the extent that the history of abolition was about rights, it centred upon property rights. ${ }^{13}$ A central argument of this article is that Mixed Commissions proceeded from a limited conception of the subject of the slave. That is not to say that Mixed Commissions did not improve the circumstances in which many enslaved individuals found themselves. Focusing on the ways in which slaves were legally framed during Mixed Commission processes does not tell the whole story about Mixed Commissions. It is however a significant narrative in the context of discussions about Mixed

${ }^{11}$ For example, Eltis compares Mixed Commission Courts unfavourably to domestic criminal courts in this respect: David Eltis, Economic Growth and the Ending of the Transatlantic Slave Trade (New York: Oxford University Press 1987), 86. He also notes that of the 1,635 slave ships either condemned, or dealt with as such, between 1808 and 1867, only 572 were adjudicated at Mixed Commission Courts between 1819 and 1845: Eltis, Economic Growth, 97.

${ }^{12}$ Martinez, The Slave Trade, 2012 (n. 9), 6. See further, the review, which contests aspects of this claim, by Philip Alston, 'Does the Past Matter? On the Origins of Human Rights Law', Harvard Law Review 126(7) (2013), 2043-2081 and further criticism of this claim in Samuel Moyn, Human Rights and the Uses of History (London and New York: Verso 2014), 54-62. Historian and legal historian Drescher and Finkelman suggest that Mixed Commissions had only a small effect on subsequent international legal theory, positioning them 'more as harbingers rather than originators'. Drescher and Finkelman, Slavery, 2014 (n. 10), 904.

${ }^{13}$ Lauren Benton, 'Abolition and Imperial Law, 1790-1820' The Journal of Imperial and Commonwealth History 39(3) (2011), 355-374, 369. 
Commission's location within a human right narrative. Although a parallel narrative, which also runs through this article, can also be told about the ways in which Commissioners sought to subvert the limitations of slave trade repression treaties, this ought not to obscure how revealing it is to examine the legal framing of the subjects of abolition. Focusing on how slaves were legally framed demonstrates some of the fundamental limitations of slave trade abolition, in particular the limited recognition of the essential humanity of slaves in international law even at the point of "rescue" by the British Royal Navy.

This main aim of this article then is to add to ongoing scholarly critiques of international criminal legal histories. In so doing it contributes to scholarly discussions about the ways in which slave trade abolition and emancipation have been remembered. ${ }^{14}$ It does so by focusing on international law. It does this by contributing a close analysis of four Mixed Commission cases in international law, for the purpose of contributing to continuing attempts to open up histories of international criminal law to further contestation and development. The article proceeds as follows. It begins by setting the British-Portuguese Mixed Commission in Sierra Leone in context and introduces key aspects of its operation. The article then moves on to iterate the central issue in the first three cases that are considered here, which flows from the fact that the ship on which slaves were being unlawfully trafficked was unlawfully captured. This proved problematic precisely because the achievement of emancipation was predicated on establishing the legality of intervention. Here it should be emphasised the article is concerned with the illegality of slave trading as a matter of international law: slavery was lawful in many national laws at this time and

\footnotetext{
${ }^{14}$ See for example Marcus Wood, The Horrible Gift of Freedom: Atlantic Slavery and the Representation of Emancipation (Athens, Georgia: University of Georgia Press 2010).
} 
developments at the international level operated within, and were restrained by, this broader context. Although this broader context is significant to an understanding of the restrictions and possibilities of international abolition, it is not the primary focus of this article, which is to explore the ways in which the subjects of abolition were framed in international treaties and the consequences thereof. This article argues that this link between emancipation and lawful intervention left slaves on board ships detained by the Royal Navy (or "re-captives" as these slaves were also known) in a potentially precarious legal position. This is because Mixed Commissions established by slave trade repression treaties were obliged to order restoration - potentially devastating sentences for re-captives on board - in many circumstances where slave ships had been unlawfully captured, even if the slave ship had been unlawfully trading. Drawing on archival material, the Sinceridade, the Activo and the Perpetuo Defensor cases, are then considered in turn. They demonstrate how emancipation under international treaties which provided for the suppression of the slave trade did not simply depend upon the condition of slavery. Similarly, it did not proceed either from any inherent right on the part of enslaved Africans to re-gain their freedom or from any nascent human right to liberty on the part of those enslaved. Rather it turned predominantly upon the question of the legality of the search, seizure and detention of the slave ship in which the slaves were found. However, in two of the cases examined here, the Activo and the Perpetuo Defensor, slave resistance subverted this invidious state of affairs. However, these narratives have been "written-out" of international legal histories, an omission which reflects the broader colonial framing of the legal archive of slave trade abolition. The remainder of the article deals with the cumulative impact of these cases. It first considers how they were received in the later and notorious Mixed Commission case, the Maria da Gloria. It then explores a series of different potential interpretation of these cases. It concludes by 
suggesting that in the present context emphasising the multivalent roles of international law in abolition is of critical importance.

\section{Mixed Commissions in context}

Once Britain had abolished its own slave trade in 1807, the government turned its attention to the foreign slave trade. As a result, British ships began to intervene against foreign suspected slave ships. Various motivations have been attributed to British abolition with the precise interplay between economic, humanitarian and other motives vigorously debated. ${ }^{15}$ Whatever the reasons for British abolition, once the Government had abolished its own trade, it was logically compelled to confront that of other states in order to minimise any economic disadvantage to Britain stemming from abolition. ${ }^{16}$ It must be remembered that the abolition of the slave trade in 1807 did not entail the abolition of slavery. ${ }^{17}$ Moreover, Britain had no legal authority to act outside its own jurisdiction so that its authority to intervene against

${ }^{15}$ See for example, Eric Williams, Capitalism and Slavery (London: Andre Deutsch 1964); Thomas Haskell, 'Capitalism and the Origins of the Humanitarian Sensibility, Part 1', The American Historical Review 90 (1984), 339-361; John Ashworth, 'The Relationship between Capitalism and Humanitarianism', The American Historical Review 92 (1987), 813-828; David Brion Davis, 'Reflections on Abolitionism and Ideological Hegemony', The American Historical Review 92 (1987), 797-812; Thomas Haskell, 'Convention and Hegemonic Interest in the Debate over Antislavery: A Reply to Davis and Ashworth', The American Historical Review 92 (1987), 829-878; Christopher Brown, Moral Capital: Foundations of British Abolitionism (University of North Carolina Press 2006).

${ }^{16}$ Suzanne Miers, Britain and the ending of the slave trade (London: Longman 1975), 9.

${ }^{17}$ Slavery was not abolished within the British Empire, and even then not everywhere, until 1833 (UK, Slavery Abolition Act, 1833, 3 \& 4 Will. IV C. 73). British abolition legislation applied to British subjects and residents, but how far it applied to British subjects abroad outside of British territory was contested. However, in 1843 Parliament affirmed that British subjects were prohibited from slave trading and slave owning everywhere (UK, An Act for the more effectual Suppression of the Slave Trade, 1843, 6 \& 7 Vic C. 98). 
foreign slave ships was limited. Initially the justification for interventions controversially rested upon the law of prize. The problem for intervenors was that this legal basis was applicable during belligerency but unavailable upon the return to the legal condition of peace. Numerous ships were condemned in the first instance at the Vice Admiralty in Sierra Leone, although many of these decisions were subsequently overturned on appeal. ${ }^{18}$ The controversy that arose from these detentions compelled Britain to seek a more consensual approach to advance slave trade abolition during peace. This impetus led to the establishment of legally innovative Mixed Commissions. In 1817 Britain and Portugal agreed to establish one Mixed Commission in British territory and another in Portuguese territory, namely in Sierra Leone (1819-1844) and Rio de Janeiro (1819-23) respectively. ${ }^{19}$ Agreements by Britain with other states to establish similar Mixed Commissions followed. These included the establishment of British-Spanish Mixed Commissions in Sierra Leone and at Havana and British-Dutch Mixed Commissions in Sierra Leone and Surinam. On Brazil's independence from Portugal, the Mixed Commission at Rio de Janeiro operated as an Anglo-

\footnotetext{
${ }^{18}$ Perhaps the most famous of which, but by no means the only, was the case of the French ship, Le Louis. England, High Court of Admiralty, Le Louis, 2 Dods. 210; 165 Eng. Rep. 1464. The illegality of condemnations by the Vice Admiralty of Sierra Leone of Portuguese, Spanish and Dutch ships between 1815 and 1817 was also recognised in the Proceeds of Captured Slavers Act. See UK, An Act for the Appropriation of certain Proceeds arising from the Capture of Vessels and Cargoes, the Property of the Subjects of the Kings of Spain, Portugal and the Netherlands, taken and Seized in Violation of the Conventions made with those States, and for granting Bounties upon Slaves captured in such Vessels, and also for granting Indemnity to the Captors of certain Vessels taken in the Prosecution of the Slave Trade, 1821, 1 \& 2 GEO. IV, c. 99.

${ }^{19}$ Additional Convention to the Treaty of the 22 January 1815, Between His Britannic Majesty and his Most Faithful Majesty, for the Purpose of preventing their Subjects from engaging in any illicit Traffic in Slaves, 18 July 1817 TNA: FO 84/2, 3
} 
Brazilian Mixed Commission (1828-1845) and an Anglo-Brazilian Mixed Commission was established in Sierra Leone. ${ }^{20}$

Each Mixed Commission operated under its own discrete bilateral treaty, but their institutional set-up was similar. The treaties establishing Mixed Commissions provided for mutual rights of search of slave ships. Search was to be carried out by members of the signatory state's navy acting under special instructions. To conduct a search an individual had to be at least of the rank of a lieutenant. Searches were instructed to be carried out in the mildest possible way. When a slave ship was captured, a prize crew would be put on board. It would then sail the slave ship to the nearest Mixed Commission with jurisdiction. When the slave ship reached the site of a Mixed Commission it was not automatic that the slaves on board would be landed. Article 8 of the Portuguese Instructions attached to the 1817 Additional Convention between Britain and Portugal provided for the landing of re-captives only in exceptional circumstances, due to 'urgent motives, deduced from the length of the voyage, the state of health of the Negroes, or other causes...' ${ }^{21}$ Even if landed, re-captives did not lose their status as slaves pending adjudication. Captors sometimes objected to the landing of slaves because the captor bore personal responsibility for damages resulting from unlawful seizures. ${ }^{22}$ In such cases the captor could be concerned that he would be obliged to

\footnotetext{
${ }^{20}$ Leslie Bethell, The Abolition of the Brazilian Slave Trade (Cambridge: Cambridge University Press 1970), 45.

${ }^{21}$ Instructions intended for the British and Portuguese Ships of War employed to prevent the illicit Traffic in Slaves attached to 1817 British-Portuguese Treaty, 1817, TNA: FO 84/2, 6.

${ }^{22}$ Portuguese Regulations for the Mixed Commissions which are to reside on the coast of Africa, in the Brazils and London, 1817, TNA: FO 84/2, 8, art 6 . The obligation to pay compensation was underwritten by the Government.
} 
provide compensation amounting to the value of the slaves if a Mixed Commission ordered slaves to be restored and actual restoration of the slaves was no longer practically possible. ${ }^{23}$

Captured slaves ships were adjudicated in the first instance by two Commissary Judges one appointed from each signatory state. Commissary Judges were not necessarily lawyers. They decided cases in open court with as little delay as possible and without the possibility of appeal against their decision. Where Commissioners disagreed, lots would be drawn for the case to be decided by one of two arbitrators, again appointed by each of the two signatory states. However, in practice due to delays in the appointment of Commissioners British Commissioners often ended up adjudicating cases alone. This gave them considerable legal advantages.

Mixed Commissions had the power either to emancipate slaves brought before them or to order the restoration of re-captives, with damages, to those claiming ownership of them. The amounts compensable were set out in article 8 of the Portuguese Regulations and reveal the ways in which slaves remained framed as property. ${ }^{24}$ On restoration, claimants recovered 'all costs of suit' and 'all losses and damages' incurred as a result of capture and detention. Amongst the heads of damages listed in the Regulations was an amount, in case of total loss, for any slaves on board the ship when it was detained. This was to be calculated by reference to the value of the slaves at the journey's end, taking into account 'the usual fair average

${ }^{23}$ See, for example, the case of the Nova Sorte, British-Portuguese Mixed Commission, The Nova Sorte, Gregory to Canning, 7 June 1823 in Class B Correspondence with the British Commissioners at Sierra Leone, the Havannah, Rio de Janeiro and Surinam, relating to the slave trade, 1823, 103, Parliamentary Papers 1824 (002) XXIV.215.

${ }^{24}$ Portuguese Regulations, 1817 (n. 22). 
mortality for the unexpired period of the regular voyage' and any charges due on sale. In other cases, 'not of total loss', owners could claim compensation for: the costs of additional subsistence provided to slaves necessitated by the detention, 'any deterioration' of slaves, and the reduction in the value of the slaves due to increased mortality or sickness as a result of the detention. Mixed Commissions had no jurisdiction over the crews of slave ships. If a ship was condemned, the re-captives on board were emancipated and the ship and its remaining cargo were sold at public auction. The profits were shared between the two Governments. Britain distributed its share of the proceeds to the captors, who received this sum on top of any award of bounties. ${ }^{25}$

Slaves emancipated by Mixed Commissions received no compensation. Article 7 of the Portuguese Regulations provided that they were to be delivered to the Government where the Commission was located, granted an emancipation certificate and 'employed as servants or free labourers'. Liberated Africans in Sierra Leone were offered either the role of apprentices in the West Indies, or enlistment with black soldiers, or a quarter of an acre of land in Sierra Leone for tilling. ${ }^{26}$ However, their freedom could be short-lived if not illusory. The fact that a slave had been legally emancipated was in practice all too often insufficient to prevent his or her re-enslavement. Emancipated Africans in Sierra Leone were considered by some to be amongst the easiest Africans to enslave. Further, the status of free labourers has been criticised as akin to slavery. ${ }^{27}$ Moreover, their status, that is whether Liberated Africans were

\footnotetext{
${ }^{25}$ Shaikh, 'Judicial Diplomacy’ 2012 (n. 9), 47. Portuguese Regulations, 1817 (n. 22), art. 7.

${ }^{26}$ Hugh Thomas, The Slave Trade: The History of the Atlantic Slave Trade 1440-1870 (London: Phoenix 2006), 688.

${ }^{27}$ Shaikh, Judicial Diplomacy 2012 (n. 9), 48 (referring to Madden's 1836 Parliamentary Select Committee testimony).
} 
in fact British subjects, remained unclear and subject to debate until 1853 when legislation made them British subjects. ${ }^{28}$

It is claimed that, overall, Mixed Commissions freed very nearly 80,000 slaves, ${ }^{29} 65,000$ of whom were freed in Sierra Leone. ${ }^{30}$ However, how the effectiveness of Mixed Commissions should be measured is contested. ${ }^{31}$ It is arguable that the existence and operation of Mixed Commissions may have prevented many more individuals from being transported. However Alston observes that around 'twenty five percent of the total number of Africans shipped to the New World ... were sent after $1807^{32}$ What is equally telling, is that Mixed Commissions did not affirm an unconditional right of freedom on the part of re-captives. Their primary focus was on the question of the legality of intervention. The status and eventual disposition of re-captives was therefore made to depend on the question of the legality of the detention of the slave ship on which they were transported, rather than on their possession of a right to re-gain their freedom. In other words, their putative liberty - if achieved - did not flow from any rights attributed to them as human beings. ${ }^{33}$

\section{Re-captives and the dilemmas of unlawful intervention}

\footnotetext{
${ }^{28}$ Philip Misevich, 'Freetown and "Freedom?” Colonialism and Slavery in Sierra Leone, 1790s to 1861' in Paul E. Lovejoy / Suzanne Schwarz (eds), Slavery, Abolition and the Transition to Colonialism in Sierra Leone (Trenton, New Jersey: Africa World Press 2015), 189-216, 206.

${ }^{29}$ Martinez, The Slave Trade 2012 (n. 9), 6.

${ }^{30}$ Shaikh, Judicial Diplomacy 2012 (n. 9), 48.

${ }^{31}$ For a discussion of some of these debates see Alston, 'Does the Past Matter' 2013 (n. 12), 2053-2054

${ }^{32}$ Alston, 'Does the Past Matter' 2013 (n. 12), 2054.

${ }^{33}$ A similar observation is also made by Moyn, Human Rights (n. 12), 59.
} 
Although Mixed Commissions had the power to emancipate slaves, their primary function was to adjudicate the legality of the capture of slave ships. ${ }^{34}$ As article 1 of the Portuguese Regulations put it, the purpose of Mixed Commissions was: 'to decide upon the legality of the detention of such Slave vessels as the cruizers of both nations shall detain'. ${ }^{35}$ To be condemned, ships must have been captured according to the procedures and limitations set out in the applicable slave trade repression treaties and in the instructions to war ships which formed an integral part of these treaties. Slave trade repression treaties assumed the continuance of the trade to a greater or lesser extent, and even where unlawful slave trading had taken place, the right to visit, search and detain slave ships was tightly constrained.

Whether a ship was lawfully detained was often a question of considerable legal complexity. These slave trade repression treaties, of course, only applied as between signatory states. Even here it was not enough that a ship was unlawfully slave trading, nor that the number of slaves on board exceeded the figure permitted by the ship's passport. A right to visit did not necessarily entail a right to detain. At least initially, Mixed Commissions were empowered to condemn ships only when slaves were actually on board. This restriction was loosened over the institutional life of Mixed Commissions as states agreed to expand powers to detain slave ships in some circumstances where slaves were not actually on board. In many cases the right to detain was also geographically circumscribed. For example, the Additional

\footnotetext{
${ }^{34}$ The emphasis on questions of intervention can also be seen from the fact that one of the first operative Mixed Commissions on the slave trade, the London Slave Trade Commission, was established solely to compensate Portuguese owners for losses arising out of unlawful interventions against Portuguese slave ships Additional Convention (Portugal), 1817 (n. 19), art 9. Reports of the London Slave Trade Commission can be found at TNA: FO 84/5; TNA: FO 84/12; TNA: FO 84/17 and TNA: FO 84/37.

${ }^{35}$ Portuguese Regulations, 1817 (n. 22).
} 
Convention between Britain and Portugal permitted the Portuguese slave trade in certain areas south of the Equator. Portugal agreed that its ships could be visited and searched north and south of the Equator, but it only consented to the detention of its ships north of the Equator. ${ }^{36}$ This meant that even if a Portuguese ship had been unlawfully slave trading north of the Equator (or indeed south of the Equator but outside those areas permitted by international law to the Portuguese to slave trade) it could not be detained south of the Equator. However, this changed in 1839 with the passage of a controversial piece of legislation, the Slave Trade (Portugal) Act, (commonly known as Palmerston's Act). ${ }^{37}$ Similar geographical restrictions applied to the detention of the slave ships of other states. In 1817 Spain agreed to abolish the Spanish slave trade north of the equator with immediate effect and to do so elsewhere after May $1820 .^{38}$ As a result, until 1820 the Anglo-Spanish Mixed Commission could only condemn ships captured north of the equator. ${ }^{39}$

\footnotetext{
${ }^{36}$ Additional Convention (Portugal), 1817 (n. 19), art 2; Portuguese Instructions, 1817 (n. 21 ), art 4.

${ }^{37}$ This statute was passed when Britain and Portugal failed to agree a new treaty which would have included inter alia the right to search south of the Equator. It permitted, inter alia, the seizure and detention of Portuguese ships, whether north or south of the Equator. The international legality of such peacetime interventions against Portuguese slave ships was profoundly problematic. Despite its protests, Portugal agreed to a new treaty in 1842, which included a mutual right of search south of the Equator: J-P Van Niekerk, 'British, Portuguese, and American judges in Adderley Street: the international legal background to and some judicial aspects of the Cape Town Mixed Commissions for the suppression of the transatlantic slave trade in the nineteenth century (part 1)', Comp. \& Int'l L J S Afri 37 (2004), 1-39, 29-31; Martinez, The Slave Trade 2012 (n. 9), 141.

${ }^{38}$ Additional Convention to the Treaty concluded at Madrid on the $5^{\text {th }}$ of July 1814 , between his Britannic Majesty and His Catholic Majesty, for preventing their Subjects from engaging in any illicit Traffic in Slaves 23 September 1817, TNA: FO 84/2, 11, arts 1 and 2.

${ }^{39}$ Instructions for the British and Spanish Ships of War employed to prevent the illicit Traffic in Slaves, 1817, TNA: FO 84/2, 14, art. 2.
} 
Inevitably, these geographical restrictions proved legally problematic. There were occasions when Mixed Commissions were confronted with slave ships which had been both illegally slave trading (for example loading their human cargo north of the equator) and unlawfully captured (for example south of the Equator). This presented Commissioners with the considerable and inter-related dilemmas of how such ships should be adjudicated and whether there were forms of illegality Commissioners could and should sanction. How these questions were resolved in any one case could have potentially devastating impact on recaptives awaiting adjudication. Their resolution also had significant financial consequences for captors, and, in turn, their government, because of their liability to compensation. These are amongst the challenging legal issues that fell to be considered in the cases this article examines, the first of which is the Sinceridade.

\subsection{The Sinceridade}

On 3 December 1822, HMS Bann seized the Portuguese ship, the Sinceridade with 123 slaves on board. ${ }^{40}$ The Sinceridade had been trading without a Royal Passport, as required by Article 4 of the Additional Convention. It had taken slaves on board south of the Equator but at a place that lay outside the area in which Portugal was permitted to trade according to Articles 1 and 2 of the Additional Convention. Hence the ship had been illegally slavetrading. However, since the Sinceridade was captured about eight miles south of the Equator its detention was also unlawful. Accordingly, the British-Portuguese Mixed Commission ordered the Sinceridade to be restored to its owners. Normally the restoration of the recaptives to the owners would also have followed. However, by this time at least half of the slaves had already been landed because they were so ill. This rendered restitution potentially

\footnotetext{
${ }^{40}$ British-Portuguese Mixed Commission, The Sinceridade (n. 3).
} 
difficult to enforce. The British Arbitrator, Fitzgerald, urged the parties to agree that the slaves should not be restored in person. This was without prejudice to the question of the claimant's entitlement to compensation for the slaves. Here the Commissioners faced an unenviable dilemma. On the one hand, allowing compensation could encourage the illegal slave trade. On the other hand, refusing compensation could encourage more slave ships to be seized unlawfully by removing a financial deterrent to unlawful interventions. As part of their accord the parties agreed that the claimant would only receive financial compensation for the slaves if the British and Portuguese Governments agreed that such a sum was appropriate, taking into account the fact that the slave trading voyage which had given rise to the unlawful detention was itself illegal. ${ }^{41}$

Consequently the Commissioners reserved the question of compensation for the loss of the slaves for the consideration of the Portuguese and British Governments. In response a British declaration to the Portuguese Government set out what became known as the Sinceridade principle:

His Majesty’s Government do not hesitate to declare their opinion, that, in point of equity, no compensation whatever can be due to traders, in case of traffick carried on under circumstances which constitute illegal trade, and doubtless on the other hand no condemnation of a vessel ought to take place, when the capture is made at a spot, not absolutely within the boundary prescribed for capture by the treaty.....His Majesty's Government believe, that the Portuguese Government will agree with them, that such

\footnotetext{
${ }^{41}$ Gregory to Canning, 6 June 1823, TNA: FO 84/22, 123.
} 
is the spirit of the treaty, particularly of the $9^{\text {th }}$ article of the instructions for the Mixed Commission. $^{42}$

The Portuguese Government did not expressly adopt this principle. However, as it did not object to it, it was taken by the British Government to have acquiesced in it. This declaration was interpreted by the British Commissioners to stand for the principle that where ships were illegally seized south of the equator, no compensation was due for incidental losses where the slave trade repression treaty had been grossly violated. ${ }^{43}$ At first sight this might appear to be a neat legal solution to the legal conundrum of what to do when an unlawfully trading slave ship was unlawfully captured. However, there were two problems with it. First, the application of the Sinceridade principle beyond the British treaty with Portugal was not automatic: rather, it depended on other states' acceptance of it. Second, its implications for re-captives awaiting adjudication were less auspicious. For this solution did not entitle recaptives on board illegally captured ships in such circumstances to be protected from restoration or to be entitled to emancipation. This was the case even if re-captives had been trafficked contrary to the provisions of the relevant international conventions.

The slaves in the Sinceridade were landed in Sierra Leone. However, this did not entitle them to emancipation certificates. Even so, the practice in cases where slaves were not formally entitled to emancipation but were not restored - whether through agreement or otherwise - was, it seems, to treat the slaves in the same way as those actually emancipated. In a context where, at least in practice, an emancipation certificate did not always protect

\footnotetext{
${ }^{42}$ Quoted in Foreign Office to King's Advocate, 11 November 1826, TNA: FO 83/2344, 96.

${ }^{43}$ Christopher Robinson to Canning, 18 November 1826, TNA: FO 83/2344, 107.
} 
liberated Africans from re-enslavement, the failure to be granted formal legal emancipation might not be thought a significant practical loss. But it is demonstrative of a legal mind-set that linked emancipation to lawful intervention. For re-captives who were not restored, the absence of an emancipation certificate may have been of little consequence. This may therefore not have been a matter of great significance. However, obtaining freedom without formal emancipation was in part down to serendipity. For beyond the case of the Sinceridade, whether other unlawfully traded slaves found on board unlawfully detained ships would be able to obtain freedom in this way would depend upon whether they were the beneficiaries of a similar agreement exempting them from restoration or, if that were not the case, in their being able to resist restoration in some other way. This latter possibility was exemplified by the cases of the Brazilian ships, the Activo and the Perpetuo Defensor.

\subsection{The Activo}

The Activo, sailing under the command of the Brazilian, Jozé Pinto, was illegally captured south of the equator by HMS Atholl on 1 February 1826. It was taken to the BritishPortuguese Mixed Commission at Sierra Leone, ${ }^{44}$ with 163 slaves on board. The evidence that six slaves gave in court 'clearly established' that all the slaves had been purchased north of the Equator. This meant that the Activo was illegally slave trading according to the Additional Convention of 1817 between Britain and Portugal, ${ }^{45}$ the obligations of which Brazil had assumed on independence. ${ }^{46}$

\footnotetext{
${ }^{44}$ British-Portuguese Mixed Commission, The Activo (n. 4).

${ }^{45}$ Additional Convention (Portugal), 1817 (n. 19).

${ }^{46}$ Bethell, Abolition (n. 20), 45.
} 
Prior to adjudication, and over the course of two to three days in late April, the re-captives, who were being detained on board with insufficient provisions and who were concerned that they might not be emancipated, forcibly rose up and escaped from the Activo to the shore. The captor sought the return of the slaves to the ship, a request which the Acting Governor, Macaulay, refused. However, the British Portuguese Mixed Commission subsequently ordered the ship and its re-captives to be restored, with damages, to the owner. By contrast with what happened in the case of the Sinceridade, the parties in the Activo refused to enter into an agreement not to restore the slaves in person. This placed the slaves in a perilous position. Luckily for them Macaulay remained firm in his refusal to return them.

Faced with evidence of both unlawful intervention and illegal slave trading, the Commissioners were placed in a similar dilemma to that which their colleagues had faced in the case of the Sinceridade four years earlier. The Activo had been captured outside the area permitted by the Additional Convention and it had been illegally slave trading this time north of the Equator. Added to which, the failure to return the slaves arose in part from a mutiny, a state of affairs which the captor's proctor relied upon to argue that any compensation awarded should exclude the value of the slaves. The Mixed Commission considered that the loss of the slaves could only be partially attributed to the captor. ${ }^{47}$ Moreover, in reaching their final award the Commissioners were at pains to avoid sanctioning: the claimant's loss of the slaves; the failure of the captor and his agent to retain the slaves on board the ship; the unlawful seizure of the Activo; and the illegal slave trading. At the same time, they held that an unconditional award of damages for loss of the slaves would violate the principles of

\footnotetext{
${ }^{47}$ It is indicative, although not unexpected, that the loss of the slaves in these circumstances was not framed in terms of their freedom or self-liberation.
} 
Equity and reward the claimant for his violation of the law. On 1 July 1826 the Mixed Commission awarded compensation. This was comprised of both an unconditional and conditional award, the former including the costs of suit and damages to the ship arising out of its detention and the latter an amount for the loss of the slaves and for demurrage. The conditional award was made dependent upon the British and Brazilian Governments affirming that payment for such losses was in accordance with the Additional Convention.

In response to the Mixed Commission's referral, the British Government sought legal advice. The King's Advocate, Christopher Robinson, approved of the Commissioners' order of restitution. However, in the absence of the kind of agreement concluded by the parties in the Sinceridade, he doubted the rectitude of the award of conditional damages. Moreover, he distinguished the position of re-captives dispatched to Sierra Leone for adjudication from the situation of fugitive slaves reaching British territory, whom it had been determined should not be returned to slavery. Since the question of the status of the slaves was highly significant, he recommended further legal advice be taken from the Attorney and Solicitor General. ${ }^{48}$ In a later opinion Robinson ventured the suggestion that since the Regulations for Mixed Commissions did not permit damages for more slaves than Portuguese law allowed a ship to carry, compensation for slaves could be denied entirely. However, ultimately he advised that the British Government should make a similar communication with the Brazilian Government to that which it had made with Portugal in the case of the Sinceridade. This strategy dealt with the question of compensation but it did not alleviate the position of the slaves, whom he doubted were entitled to liberation. ${ }^{49}$

\footnotetext{
${ }^{48}$ Christopher Robinson to Canning, 30 October 1826, TNA: FO 83/2344, 90.

${ }^{49}$ Christopher Robinson to Canning, 18 November 1826, TNA: FO 83/2344, 107.
} 
In contrast, the Governmental authorities in Sierra Leone sought to apply Somerset's Case to the situation of the re-captives in the Activo. Somerset's Case was widely taken at the time to have abolished slavery in England, although strictly speaking the decision of the case was that a master could not forcibly remove a slave from England. ${ }^{50}$ The legal advice the British Government received on the Activo case (and that of the Perpetuo Defensor considered in the next section) was that Somerset's principle did not apply to slaves brought to Sierra Leone for adjudication before Mixed Commission Courts. This was because the principle drawn from Somerset's Case, that a slave enjoyed freedom by presence on British territory alone was not 'an abstract or universal principle'. It could not be applied to the disembarkation of re-captives under the slave trade repression treaties. It followed that the slaves in the Activo should have been restored. ${ }^{51}$ This opinion rested upon a fundamental contradiction when applied to the territory of Sierra Leone, which was a colony established for freed slaves and the focus of the British Government's assault on the slave trade. ${ }^{52}$

\footnotetext{
${ }^{50}$ English King's Bench, Somerset v. Stewart (1772) Lofft 1; 1772 KB 98 Eng. Rep. 499. See, for example, Paul Finkelman, An Imperfect Union: Slavery, Federalism and Comity (Chapel Hill: North Carolina University Press 1981); Cheryl Harris, “'Too Pure an Air”: Somerset’s Legacy from Anti-Slavery to Colorblindness', Tex. Wesleyan L. Rev 13 (2006-2007), 439-458; William Wiecek, 'Somerset: Lord Mansfield and the Legitimacy of Slavery in the Anglo-American World', University of Chicago Law Review 42 (1974-1975), 86-146.

${ }^{51}$ Doctors Commons to Canning, 26 January 1827, TNA: FO 83/2344, 132.

${ }^{52}$ See, for example, Christopher Fyfe, A History of Sierra Leone (Aylesbury and Slough: Oxford University Press 1962); Simon Schama, Rough Crossings: the Slaves, the British, and the American Revolution (New York: HarperCollins 2006); Paul Lovejoy/Suzanne Schwarz, 'Sierra Leone in the Eighteenth and Nineteenth Centuries' in Paul Lovejoy / Suzanne Schwarz (eds), Slavery, Abolition and the Transition to Colonialism in Sierra Leone (Trenton New Jersey: Africa World Press 2015), 1-28.
} 
The Mixed Commission's decision in Activo did little to alleviate the legally precarious position of unlawfully traded slaves found in unlawfully captured ships as a matter of general principle, although the re-captives in this case obtained their freedom. As a matter of general principle it was more successful in minimising the financial liabilities of intervenors than in advancing the legal position of the slaves. At best it is of course possible to read the award of conditional damages in these cases as the "price" paid for the non-restoration of the slaves. In the end the master of the Activo was not paid an award for the slaves. But the British government paid compensation of $£ 157.8 \mathrm{~s}$ in excess of the unconditional award ordered by the Mixed Commission. ${ }^{53}$ From at least two perspectives, that of the legal construction of the victims of the slave trade and the lack of certainly surrounding their eventual disposition, the overall outcome in this case was problematic because it depended upon an element of serendipity: that is whether the re-captives managed to make it to the shore. Had the recaptives on board not successfully risen up against their continued detention, restitution would presumably have gone ahead. The decision on damages did nothing to alleviate that risk as a matter of general principle. Even so, the Activo's use of a conditional monetary award was applied to similar facts in the case of the Perpetuo Defensor.

\subsection{The Perpetuo Defensor}

The Perpetuo Defensor had illegally embarked slaves north of the Equator but, like the Activo and Sinceridade, had been captured south of it, in April 1826, this time by Captain Bullen of the Maidstone. ${ }^{54}$ Although 473 slaves had been originally trafficked, 49 had perished before the Perpetuo Defensor was captured. On the capture of the Perpetuo

\footnotetext{
${ }^{53}$ Shaikh, Judicial Diplomacy 2012 (n. 9), 51.

54 British-Portuguese Mixed Commission, The Perpetuo Defensor (n. 5).
} 
Defensor one of the surviving slaves, Cacow, who claimed to be a British subject, was immediately removed to the Maidstone. When the Perpetuo Defensor arrived in Sierra Leone on 23 May, the slaves who had survived were in a pitiful state and immediately quarantined. To that end, around 240 healthy slaves were placed on board a colonial government ship, the Susan, and the sick were left on board the Perpetuo Defensor. Cacow died on 27 May.

Initially, Bullen sought to justify his detention of the Perpetuo Defensor on the basis that the ship had detained a British subject on board. On 13 June he dropped this claim when he was informed that the British-Portuguese Mixed Commission was unable to adjudicate on that ground. As a result, Bullen sought to restore the ship and the re-captives to the master of the Perpetuo Defensor. However, the master rejected this proposal, demanding the case go before the Mixed Commission because he wanted to recover damages on top of the restoration of the ship and the re-captives. This insistence on adjudication placed the Mixed Commission in a similarly difficult position to the one in which it had found itself in the Sinceridade. For it was required to determine the disposition of a ship and its human cargo where the ship had been unlawfully slave trading and unlawfully captured. Meanwhile the re-captives were waiting to learn their fate.

The quarantine period terminated at the end of June 1826. On 4 July, in the presence of the British Commissary Judge, the Chief Justice of Sierra Leone denied the second of two habeas corpus applications that had been brought in respect of the re-captives on board the Perpetuo Defensor. The following day, without the Mixed Commission's permission, the re-captives on board the Susan were landed on the orders of the Acting Governor. By this time, 88 re- 
captives were left on board the Perpetuo Defensor. They had been encouraged by re-captives on board the Susan, and by one member of the Maidstone, to rise up against the crew of the Perpetuo Defensor. Fearing for his life and the lives of the remaining members of his crew, the Master of the Perpetuo Defensor consented to the landing of the re-captives on 6 July. When the Mixed Commission finally adjudicated on 28 September it followed its previous practice. It granted, in addition to unconditional damages, a conditional award for the total loss of 364 slaves. In line with past practice, it made the conditional award dependent upon the British and Brazilian Governments affirming that its payment would be in accordance with the Additional Convention. Here again, the re-captives were treated to all intents and purposes as if they had been emancipated, but the Mixed Commission's legal gymnastics meant that it did not determine the question of re-captives' protection from restoration as a matter of general principle.

The Mixed Commission's reference on the question of providing compensation for illegally traded slaves who had been illegally re-captured proved inconclusive. The British Government received further legal advice to the effect that indemnification for the loss of the slaves in these circumstances was not in accordance with the 'object and spirit of the treaties' because it could not have been intended that 'a direct violation of its provisions should be made the subject of a legal demand for indemnity.' Thus the advice stated, the violation of the prohibition on capture south of the Equator could at most give rise to a claim for restitution of the ship; it could not be the basis of a claim for compensation for slaves. Even so, it was suggested that the refusal of compensation claims in these circumstances should be a matter for inter-state negotiations rather than a question of general guidance to Commissioners. This was because it involved replacing 'the spirit and intention of the treaty' 
for its 'strict letter'.55 The prospects of such inter-governmental agreement were slim however. The British Government had proposed a joint declaration with Brazil, one that would have legalised the capture of all slave ships found in locations where it was unlawful to slave trade. However, Brazil persisted in its claims for compensation. Faced with this impasse, the British Government's legal advice suggested that all the Government could do was to persist in its attempts to conclude an agreement with Brazil. It was also suggested that any such agreement should include provision for the liberation of those slaves who had been trafficked outside the areas in which Brazil was permitted to trade. ${ }^{56}$

As far as the British Mixed Commissioners were concerned, the Activo and the Perpetuo Defensor cases established the legal principle that no compensation for slaves was due to claimants whose illegally captured ships were restored to them when the slaves they carried had been loaded onto ships outside areas where it was lawful to trade. ${ }^{57}$ The problem from the perspective of re-captives was that the rejection of compensation in these circumstances did not directly address the question of their restoration. For his part, Secretary of State Canning approved of the Commissioners' decree of restoration in those cases where ships had been illegally trading and unlawfully captured, as in the cases of the Activo and the Perpetuo Defensor. However, he did so subject to recognising 'special Cases'. So, where 'unforseen circumstances' rendered a decree of restoration impossible, he advised that the Commission should use its discretion but should not order emancipation. Rather, he

\footnotetext{
${ }^{55}$ Doctors Commons to the Earl of Dudley, 23 May 1828, TNA: FO 83/2344, 275.

${ }^{56}$ King's Advocate Memo on the Cases of the Activo and the Perpetuo Defensor, 22 September 1828 TNA: FO $83 / 2344,303$.

${ }^{57}$ HM Commissioners to the Earl of Aberdeen, 16 February 1829, TNA: FO 84/90, 41, 42.
} 
explained, slaves should be 'placed under the superintendence of the Local Government by some Conditional Order.' 58

What is clear is that this uneasy accommodation left re-captives in a potentially more precarious legal position than that of their "rescuers". As the King's Advocate observed, it would have been preferable had the Commissioners reserved an altogether different question for him to consider. For him, the distinction the Commissioners had opened up between the slaves and their value was untenable. In his view it would have been better to ask whether claimants should be able to claim restitution at all in cases where unlawfully captured ships had been slave trading in violation of international treaties. ${ }^{59}$ If that question had been posed, then it might have allowed for a more radical challenge to the link between lawful intervention and emancipation, thereby alleviating the resulting legal precariousness of slaves "rescued" by the British Royal Navy. Why such a pertinent question was not asked must remain a matter of conjecture. But its absence highlights how the legal tools at Commissioners' disposal directed their focus towards questions of intervention and financial liabilities rather than towards the rights of the slaves. Presumably this also reflected the preoccupation of Commissioners.

\section{Restoration - freedom denied}

The precariousness of these principles for re-captives was evident a few years later in the notorious case of the Maria da Gloria, in which illegally traded slaves found on board an

\footnotetext{
${ }^{58}$ Canning to HM Commissioners, 30 December 1826, TNA: FO 84/49, 7.

${ }^{59}$ King's Advocate Memo on the Cases of the Activo and the Perpetuo Defensor (n. 56), 311. See further, Christopher Robinson who also suggested a re-phrasing of the reference. Christopher Robinson to Canning, 18 November 1826, TNA: FO 83/2344, 107.
} 
unlawfully captured ship were in fact returned to those claiming ownership of them. ${ }^{60}$ Here then the consequences for re-captives of the apparently neat legal device adopted in the Activo and Perpetuo Defensor cases were brutal.

On 25 November 1833, the British ship HMS Snake captured the slave ship the Maria da Gloria just beyond Rio harbour. The Maria da Gloria had been unlawfully slave trading, having shipped a cargo of slaves at Angola around 26 October without a Royal Passport permitting the slave trade. Therefore it was in violation of article 4 of the Additional Convention between Portugal and Britain. Over 400 slaves, at least half of whom were young children, ${ }^{61}$ were on board. The ship was brought before the British-Brazilian Mixed Commission. The Commissary Judges at Rio de Janeiro declined to exercise jurisdiction on the grounds that the ship was Portuguese. So the prize crew sailed the ship for 46 days to Sierra Leone in search of a court with jurisdiction and brought the ship before the British Portuguese Mixed Commission there. Between the capture of the Maria da Gloria and its reaching Sierra Leone 78 of its human cargo had died. Many of those remaining were in a sickly state and five more died after arriving at Sierra Leone. Two and a half months later adjudication took place. ${ }^{62}$ The Mixed Commissioners unwillingly restored the Maria da Gloria to her owners because the capture had taken place south of the Equator and, therefore, illegally. As a result of the Commissioners' ruling, on 9 April 1834, 240 slaves were compelled to make a third journey on board the Maria da Gloria across the Atlantic. Sixtyfour slaves who were considered too sick to make the journey remained in Sierra Leone.

\footnotetext{
${ }^{60}$ British-Portuguese Mixed Commission, The Maria da Gloria (n. 6).

${ }^{61}$ Bethell, Abolition (n. 20), 135.

${ }^{62}$ Robert Burroughs, 'Eyes on the Prize: Journeys in Slave Ships Taken as Prizes by the Royal Navy', Slavery and Abolition 31(1) (2010), 99-115, 110.
} 
Bethell observes that although the slaves sent to Brazil were eventually emancipated according to an 1831 Brazilian law, by the time this took place most had already been sent onto plantations, which rendered the enforcement of their emancipation practically impossible. $^{63}$

The application of the so-called Sinceridade principle rested on an inherently contradictory legal compromise. The principles laid down in the Sinceridade, the Activo and the Perpetuo Defensor cases were taken to prevent claimants obtaining indemnification for the loss of slaves and demurrage in cases of illegally captured ships carrying unlawfully trafficked slaves. Yet, they did not prevent the restoration of re-captives. Thus Commissioners, when applying these cases to the Maria da Gloria, proceeded from what they considered had now become a settled principle that claimants were not entitled to damages for the loss of the slaves or for demurrage, but they still felt obliged to order the restoration of the ship and cargo, including its human cargo, because of the unlawful capture. In fact, in the Maria da Gloria Commissioners went even further than in the previous three decisions. They made the award of the costs of suit and other damages, which in the previous cases had been granted unconditionally, provisional upon the British and Brazilian Governments agreeing the payment of such sums was in accordance with the Additional Convention. As noted previously, the King's Advocate recognised this unhappy legal inconsistency between the approach adopted to the slaves on the one hand and that adopted to their value on the other. ${ }^{64}$

\footnotetext{
${ }^{63}$ Bethell, Abolition (n. 20), 136.

${ }^{64}$ King's Advocate Memo on the Cases of the Activo and the Perpetuo Defensor (n. 56).
} 
It is undoubtedly the case that Mixed Commissions emancipated slaves who would otherwise have been sent across the Atlantic and forced to endure the trauma of compulsory labour, further displacement and violence. It is also worth remembering that many liberated Africans at Sierra Leone were also displaced and that legal emancipation did not equate to unconditional freedom. ${ }^{65}$ Moreover, Mixed Commissions did not position slaves as rights holders, even where restoration was avoided as in the cases of the Activo and the Perpetuo Defensor. Admittedly, the actual restoration of slaves at Sierra Leone as in the case of the Maria da Gloria was unusual. In a number of cases the actual restoration of re-captives who were not formally entitled to emancipation was avoided. Sometimes masters of slave ships agreed to manumit slaves, or simply took the decision not to claim them. However, this was a serendipitous outcome and therefore did not detract from the legal precariousness of the state of re-captivity. Thus even at the point of "rescue", slave trade repression treaties did not fundamentally challenge the legal framing of the human subject that underpinned the institution of slavery. This led in the case of the Maria da Gloria to the actual return of recaptives to those claiming ownership over them. In this way slave trade repression treaties can be seen as complicit in slavery. This criticism might be considered out of place given the broader legal context within which slave trade repression treaties were drafted and Mixed Commissions operated. It nevertheless remains an important one. For it demonstrates the limits of slave trade abolition under international law during this period. This in turn raises critical questions concerning how abolition and international law's role in it should written into international (criminal) law.

\section{Remembering abolition}

\footnotetext{
${ }^{65}$ See text to n. 27.
} 
A number of overlapping narratives emerge from this encounter with the archive. This does not make remembering abolition a straight-forward enterprise. For it is evident that writing such an account is not simply a matter of archival retrieval, but involves profound, political ethical and methodological choices. ${ }^{66}$ In his masterful analysis of C.L.R James's The Black Jacobins David Scott asks the critical question: 'What mode of emplotment of the past might best enable a critical rethinking of the present we inhabit such as to open up new ways of thinking about possible futures? ${ }^{97}$ It is clear that the challenge of history writing is not simply one of re-constructing the past. It is also a challenge of, and to, the present.

Slave trade repression treaties were limited in a number of ways. ${ }^{68}$ The question remains how a narrative about these limitations can and should be constructed. One narrative might emphasise how Commissioners struggled with the limited legal tools at their disposal to sidestep the limitations of the slave trade repression treaties. Another narrative might focus on how the formal legal framework of abolition failed to recognise the humanity of slaves because it focused on questions of intervention and property. A third narrative might emphasise how slave resistance challenged the legal limitations of the slave trade repression

\footnotetext{
${ }^{66}$ For discussion of contributionists and critical theorists in the context of writing about international law and Africa, see James Thuo Gathii, 'Africa' in Bardo Fassbender/Anne Peters (eds), The Oxford Handbook of the History of International Law (Oxford: Oxford University Press 2014), 407-428.

${ }^{67}$ David Scott, Conscripts of Modernity: The Tragedy of Colonial Enlightenment (Durham and London: Duke University Press 2004), 50.

${ }^{68}$ See text to n. 35-39.
} 
treaties. The fact that these narratives can be read alongside each other, begs the question of how Mixed Commissions might be assessed, and with what effect in the present. ${ }^{69}$

\subsection{A Struggle with Limited Legal Tools}

From one perspective Mixed Commissions might be assessed by the extent to which they were able to advance abolition within the limited framework set by slave trade repression treaties and within a broader legal context in which the slave trade and slavery were only exceptionally prohibited at this time. From this perspective the Commissioners in the Sinceridade, Activo and Perpetuo Defensor can be seen to have struggled with the limited legal tools at their disposal in order to sidestep some of the limitations of the slave trade repression treaties through strategic referrals to the executive and creative awards of damages. Commissioners and intervenors had to walk a tightrope between the demands of legality and any impetus they might have felt towards abolition. Individual Commissioners struggled with how to weigh one form of illegality (slave trading) against another (unlawful capture). When Fitzgerald urged the parties in the Sinceridade to reach an agreement not to restore the slaves, it appears he was motivated by a strong desire to avoid slaves being restored to a slave ship. His concern was exacerbated because the ship's provisions had been largely spent, thereby exposing restored slaves not only to the risk of further enslavement but also to starvation on the onward journey to the Americas. This was no doubt a matter of

\footnotetext{
${ }^{69}$ For further discussion see Alston, 'Does the Past Matter' 2013 (n. 12), 2053-2055 reviewing various possible criteria for assessing Mixed Commissions including: the number of slaves they emancipated; the number of individuals who might otherwise have been enslaved but for the existence of the Commissions; the post emancipation experiences of former slaves; and the contribution Mixed Commissions made to the abolition of slavery.
} 
genuine humanitarian concern to him but it should be noted he also considered it to be a matter of fairness towards the claimants not insist that the master of the ship 'accept the slaves without the means of subsisting them. ${ }^{70}$

Commissioners were of course legally constrained by their constituent instruments and these were in turn dependent upon the vagaries of state consent. As Fitzgerald observed:

The Commissioners are, it is to be hoped, never insensible to the feelings of humanity, never wanting in sympathy for the sufferings of the oppressed, nor in aversion for the oppressors. But under the Treaties which form the law of these Commissions, enslaved Africans can be liberated, and nefarious Slave-traders can be punished, only so far as the Treaties will admit. ${ }^{71}$

From this perspective it might be argued that Mixed Commissioners did what they could to limit the slave trade, using the limited tools at their disposal to advance abolition within the framework of international treaties. From this perspective an important question to ask is: what more might Commissioners have done? This then is essentially a narrative about a progressive institutional struggle against injustice. However, this line of enquiry leaves the broader legal framing of abolition untouched. Therefore, it is also important to understand how re-captives were legally framed at the point of putative rescue. Such framing points to

\footnotetext{
${ }^{70}$ Statement of the Proceedings of the British and Portuguese Court of Mixed Commission, upon the Question of Compensation and Damages, Consequent upon the Restitution of the Portuguese Schooner Sinceridade, TNA: FO 84/22, 133.

${ }^{71}$ Fitzgerald's Opinion on the Case of the Portuguese Schooner Sinceridade, TNA FO: 84/22, 120.
} 
some of the limits of abolition which demand recognition in international law. It also suggests that international law's support of the slave trade was far from redeemed by its contribution to abolition.

\subsection{The Legal Framing of the Subjects of Abolition}

The extent to which these particular proceedings contain expressions of judicial concern for the well-being of slaves on board illegally captured ships must be properly understood within their specific legal context. For these cases show how emancipation under international legal treaties was primarily determined by reference to the question of the legality of intervention by slaving and former slave states, rather than by any legal recognition that enslaved Africans had an inherent right to freedom.

Under slave trade repression treaties the legal dependency of emancipation on the question of the legality of any particular intervention led to a highly circumscribed path to freedom with the result that re-captives were placed in a legally precarious position. Thus recaptivity promised but did not guarantee the transition from enslavement to emancipation. Even where actual restoration was avoided, the threat of restoration was omnipresent. This outcome was avoided in some of the cases examined here through a combination of slave resistance, strategic awards of damages and the actions of the colonial government. However, as the case of the Maria da Gloria demonstrates this did not advance the rights of slaves and recaptives found in similar circumstances as a matter of general principle. In contrast the legal outcome did more to minimise the legal liabilities of captors and the guarantor governments to pay compensation. 
Examining the legal framing of the subjects of abolition illuminates the compromises and limitations of a system of adjudication which was bound to the legal structures of property and techniques of representation that underpinned the institution of slavery. ${ }^{72}$ The question of the framing of the legal subject is not the only narrative that can be told about Mixed Commissions but it is a significant one. And the relevance of this particular critique is not lost even if the Mixed Commissions regime had been more effective, that is had the Navy stopped more ships and had it only conducted lawful interventions. For even if that had happened slaves and re-captives would still have been considered as potentially compensable property whose path to emancipation depended upon the prior question of the legality of the intervention and not upon their essential humanity.

\subsection{Resistance $^{73}$}

Whatever their formal legal position, re-captives were not simply objects of intervention. For instance re-captives altered the legal course of events by escaping from the Activo and rising

\footnotetext{
${ }^{72}$ Scott locates the tragedy of Toussaint Louverture in the fact that 'he must seek his freedom in the very technologies, conceptual languages, and institutional formations in which modernity's rationality has sought his enslavement' Scott, Conscripts of Modernity (n. 67), 168.

${ }^{73}$ On the role of resistance in international law more generally, see Balakrishnan Rajagopal, International Law from Below: Development, Social Movements and Third World Resistance (Cambridge: Cambridge University Press 2003), and in human rights more specifically, see Neil Stammers, 'Social Movements and the Social Construction of Human Rights', Human Rights Quarterly 21 (1999), 980-1008. The literature on slave resistance is extensive. The ground-breaking narrative of the Haitian Revolution can of course be found in C. L. R. James, The Black Jacobins: Toussaint L'Ouverture and the San Domingo Revolution (London: Penguin Books 1980). See further Jacques Depelchin, Reclaiming African History (Cape Town, Dakar, Nairobi and Oxford: Pambazuka Press 2011).
} 
up against the crew of the Perpetuo Defensor, actions which were seized upon by the colonial authorities. $^{74}$ By reaching the shore, re-captives from the illegally captured Brazilian ships the Activo and the Perpetuo Defensor revealed the contradictions inherent in the scope and application of emancipation under slave trade repression treaties. In so doing, they made manifest the limitations of international law and contributed to the generation of legal change. The first narrative examined here, the struggle with limited legal tools, emphasised how Mixed Commissions subverted some of the limitations of the slave trade repression treaties. The resistance narrative presented here emphasises that at least in the Activo and Perpetuo Defensor cases, Commissioners could not have done so without slave resistance. Even Canning's pragmatic advice to Commissioners, in which he acknowledges that 'unforeseen circumstances' might render a decree of restoration impossible, can be read as an implicit recognition of slave resistance.

Mixed Commissions were not simply fora where emancipation was given or withheld. They were also sites of struggle, including struggles by re-captives against the logics and frameworks of international abolition law. Out of those struggles multifaceted international legal subjects emerge. How consciously slaves resisted international law or manipulated the contradictions inherent in British obligations under the 1817 Treaty with Portugal and the logic of Somerset's Case remains an open question. Notwithstanding the inevitable limitations of the legal archive as a historical source for gleaning information about the motivations and actions of re-captives, the evidence suggests that re-captives and liberated Africans were far from passive objects. Certainly, it was observed on behalf of the claimant

\footnotetext{
74 This points to a narrative which is not explored here, namely the disagreement between colonial authorities and the Mixed Commission with the former refusing to hand over re-captives subject to orders of restoration.
} 
in the Perpetuo Defensor case that contact between the slaves on board the Perpetuo Defensor and liberated Africans at Sierra Leone had made the former rebellious. ${ }^{75}$ Their contact with liberated Africans therefore lends credibility to the assumption that at least some re-captives appreciated the potential significance of their reaching the shore, even if they did not understand the finer legal details of their position.

Re-captives in the Activo and the Perpetuo Defensor cases resisted international law. They gained their freedom despite orders of restoration issued according to the British-Portuguese Treaty. Their resistance also contributed to a shift in the practice regarding compensation. That said even though their resistance led to their own "freedom", it was not able to alleviate the legal precariousness of re-captivity as a matter of general principle. This emerges most clearly in the case of the Maria da Gloria, a decision which also shines a vital and critical light on the nature and limitations of international abolition law.

At a broader level it is striking that all of these cases, and the role of the re-captives in them, have been excluded from international criminal legal histories. ${ }^{76}$ The failure to account more broadly for slave resistance in international, specifically international criminal, legal histories has been informed by colonially driven assumptions about legal agency. ${ }^{77}$ By contrast,

\footnotetext{
${ }^{75}$ British-Portuguese Mixed Commission, The Perpetuo Defensor (n. 5).

${ }^{76}$ On silences in history, see Michel-Rolphe Trouillot, Silencing the Past: Power and the Production of History (Boston: Beacon Press 2015), 26.

${ }^{77}$ On the relationship between the archive and colonial power see, for example, Carolyn Steedman, 'After the Archive', Comparative Critical Studies 8 (2011), 321-340 and Renisa Mawani, 'Law's Archive' Annual Review of Law and Society Science 8 (2012), 337-365, 341-346.
} 
historians of British abolition have increasingly come to accept the need for more multicultural accounts, rejecting so-called imperial histories of abolition. ${ }^{78}$ One aspect of this is the recognition that the credit for abolition did not lie exclusively with white abolitionists, but also with slaves and former slaves. Of course this broad shift in focus reveals little new to those who are typically positioned only as the recipients of abolition. ${ }^{79}$ Even so, it is worth emphasising here. For international legal scholarship has been slower to embrace the implications of this broader shift for narratives about the development of international criminal law. The failure to acknowledge such acts of resistance perpetuates a silence that leads to an incomplete historical understanding of the complex dynamics and limitations of international law. For a nuanced reading of the Activo and Perpetuo Defensor cases reveals that victims of the slave trade were not simply the recipients of abolition. Through their deeds they were powerful critics of the law's limitations and contradictions. Through their actions they contributed to shaping it.

\footnotetext{
${ }^{78}$ For a discussion of imperial and multicultural narratives of abolition see, for example, John Oldfield, 'Chords of Freedom' Commemoration, ritual and British transatlantic slavery (Manchester: Manchester University Press 2007), 173. See further Eric Williams, Capitalism and Slavery (n. 15). The extent of this shift in perspective should not be over-emphasised however. For continued criticism of the representation of abolition see Depelchin, Reclaiming African History 2011 (n. 73); Wood The Horrible Gift 2010 (n. 14).

${ }^{79}$ Depelchin observes that what is apparently discovered by social scientific research is commonly long known by those who have actually experienced the object of that study. He argues that this appropriation of knowledge and of the fact of discovery perpetuates unequal relations of power. See Jacques Depelchin, Silences in African History: Between The Syndromes Of Discovery And Abolition (Dar Es Salaam: Mkuki Na Nyota Publishers 2005), 7-8. For criticism of the gift trope and its persistence in representations of abolition see Wood
} The Horrible Gift 2010 (n. 14). 


\section{Conclusion}

Mixed Commissions were early institutional sites where international law was confronted with victims on a multiple scale. Clearly, it is important to exercise caution before drawing general conclusions about the operation and legal preoccupations of Mixed Commissions from a handful of cases which took place at one site only. Mixed Commissions also evolved over their institutional life. This article has identified how Commissioners were able to creatively sidestep some of the limitations of international abolition law. However, a central aspect of the Mixed Commission regime, that is the focus on intervention, did little to directly further the legal rights of slaves on unlawfully captured ships brought in for adjudication. These cases exemplify that at the point of "rescue" victims of the slave trade found themselves in a profoundly precarious legal position. The resolution of the dilemma of what to do with unlawfully trafficked slaves in unlawfully captured ships was deeply unsatisfactory. For one thing the outcome failed to provide a secure basis for emancipation. However, in those cases where re-captives were able to reach the shores of Sierra Leone and obtain their freedom, their actions stimulated some legal change and shone a critical light on the focus of international abolition law. At a time when the legitimacy of international criminal law, more specifically the International Criminal Court's (ICC) focus on African situations, is profoundly affected by international law's historic implication in slavery and colonialism, histories of abolition which emphasise the multivalent roles of international law in abolition are of critical importance. Incorporating the resistance of slaves and re-captives, as well as the limitations of international abolition law, into international criminal legal histories is long overdue. 